\title{
THE SASKATCHEWAN NATURAL HISTORY SOCIETY
}

\author{
BOARD OF DIRECTORS (October, 1969, to October, 1970)
}

Honorary President

President.

Past President.

First Vice-President.

Second Vice-President.

Treasurer

Corresponding Secretary...

Recording Secretary.

\section{REPRESENTATIVES AT LARGE}

Ron Austin, Prince Albert; Harvey Beck, Calgary; Tom Gentles, Regina; Donald Hayward, Wolseley; Ernie Kuyt, Fort Smith, N.W.T.; Mrs. Lillian McBean, Swift Current; Murdock Nelson, Moose Jaw; Robert W. Nero, Winnipeg; Frank Roy, Saskatoon; C. Shulver, Lafleche; Mrs. Mary Skinner, Indian Head; Mrs. Sylvia Van Brienen, Rosetown.

\section{PRESIDENTS OF LOCAL NATURAL HISTORY SOCIETIES}

Miss Keitha Francis, Maple Creek Hospital, Maple Creek; Gordon Silversides, 1201 Grace St., Moose Jaw; Dr. G. B. Howard, 47 21st E., Prince Albert; J. R. Jowsey, 2635 19th Avenue, Regina; Ewen Coxworth, Saskatoon; Dr. Jan Looman, Experimental Station, Swift Current; Frank Switzer, 140 Logan Cres. W., Yorkton.

\section{APPOINTED DIRECTORS}

Blue Jay Archives: Gary Seib, 1928 Robinson Street, Regina; Blue Jay Bookshop: Frank Brazier, 2657 Cameron Street, Regina; Circulation: Lorne Scott, Saskatchewan Museum of Natural History, Regina; Conservation: Doug Whitfield, 1306 Melrose Avenue, Saskatoon; Editor of Newsletter: James Slimmon, 2526 Hanover Avenue, Saskatoon; Local Societies: James Wedgwood, 610 Leslie Avenue, Saskatoon; Office Services: James Jowsey, 2635 Nineteenth Avenue, Regina; Publicity: Ruth Shaw, Yorkton; Special Publications: C. Stuart Houston, 863 University Drive, Saskatoon; Youth: Frank Switzer, 140 Logan Crescent, Yorkton.

\section{THE BLUE JAY}

Blue Jay Editors: George F. Ledingham; Assistant Editors: Margaret Belcher, Robert W. Nero; Junior Naturalists: Joyce Deutscher.

All items for publication should be submitted to George F. Ledingham, Editor, 2335 Athol Street, Regina.

\section{MEMBERSHIPS}

The classes of memberships in the Saskatchewan Natural History Society are as follows: Regular, $\$ 3.00$; Supporting, $\$ 5.00$; Sustaining, $\$ 10.00$. The Blue Jay and Newsletter are sent without charge to all members not in arrears of dues.

Send all renewals and new memberships to James Jowsey, SNHS, P.O. Box 1121, Regina.

\section{REPRINTS}

Requests for quantities of reprints of any article printed in the Blue Jay should be sent to Printcraft Ltd., Regina, Sask., within one month of publication. Contributors wishing a few extra copies of the current Blue Jay may get them at cost. Requests for these should be made to the Editor when material is submitted for publication. 